\title{
PENGARUH MARKETING MIX DAN KUALITAS PELAYANAN \\ TERHADAP KEPUTUSAN PEMBELIAN SMARTPHONE OPPO DI MATAHARI SINGOSAREN SURAKARTA
}

\author{
Ratih Witayana Trian Soeripto ${ }^{1}$ \\ Kasidin ${ }^{2}$ \\ ${ }^{1,2}$ Program Studi Manajemen \\ Sekolah Tinggi Ilmu Ekonomi Atma Bhakti Surakarta \\ Email : kasidinsala@gmail.com
}

\begin{abstract}
The research purpose was determined the effect of Product Quality, Product Price, Promotion and Service Quality on OPPO Smartphone Purchase Decision at Matahari Singosaren Surakarta.This research was conducted in Matahari Singosaren Surakarta with multiple linear regression analysis techniques. The sample is 100 respondents. Based on the analysis results can be known Variable Quality products, Product Price, promotion and Service Quality positively affect oppo smartphone purchasing decisions in Matahari Singosaren Surakarta. Price is the most dominant variable, this can be shown with the highest regression coefficient of 0.638. Based on the results of the determination coefficient, the calculation of the SPSS program obtained a value of $R$ Square $=0.491$. This value means that Variable Product Quality, Product Price, Promotion and Service Quality contribute $49.1 \%$ to purchasing decisions on OPPO smartphones in Matahari Singosaren Surakarta. While the remaining $50.1 \%$ is influenced by other factors outside the researchers.
\end{abstract}

Keywords: product quality, product price, promotion and service quality against purchasing decisions

\section{PENDAHULUAN}

Pemasaran merupakan suatu kegiatan penting yang perlu dilakukan oleh perusahaan, baik pada perusahaan barang maupun jasa dalam upaya menjaga kelangsungan hidup usahanya. Hal tersebut dikarenakan oleh pemasaran yang menjadi suatu kegiatan perusahaan yang secara langsung berhubungan dengan konsumen. Pemasaran dilakukan suatu perusahaan dalam usahanya untuk memberikan kepuasan terhadap konsumen sesuai dengan keinginan serta kebutuhan konsumen. Salah satu inti yang menjadi halangan dalam pemasaran yaitu jumlah pesaing pada pasar tersebut, baik dari kualitas produk sejenis 
Pengaruh Marketing Mix.................................................Ratih Witayana, Kasidin ataupun dari kualitas produk lain. American marketing association memberikan definisi secara formal sebagai berikut: pemasaran yaitu sebuah fungsi organisasi dan serangkaian proses untuk menciptakan, mengkomunikasikan serta menyampaikan nilai kepada pelanggan. Selain itu, juga untuk mengelola keterkaitan pelanggan melalui cara yang menguntungkan organisasi dan pemangku kegiatannya. Berdasarkan definisi Philip kotler, pemasaran merupakan suatu proses sosial dan manajerial dimana tiap individu dan kelompok mendapatkan sesuatu yang dibutuhkan dan inginkan dengan menghasilkan dan saling menukarkan kualitas produk-kualitas produk serta nilai satu sama lain.

\section{KAJIAN PUSTAKA DAN PENGEMBANGAN HIPOTESIS}

Menurut Kotler dan Amstrong (2001) adalah segala hal yang dapat ditawarkan ke pasar agar mendapatkan perhatian, dibeli atau digunakan yang dapat memuaskan keinginan maupun kebutuhan. Fenomena kualitas produk smartphone OPPO pada Matahari Singosaren Surakarta ini adalah smartphone OPPO hadir dengan fitur-fitur terbaik dan menarik konsumen. Karena yang berkualitas menjadi suatu hal unggul yang dimiliki smartphone OPPO dibandingkan dengan Smartphone lainya dengan tingkat harga yang sama. OPPO smartphone adalah salah satu kualitas produk smartphone yang berbasis android dan belum lama memiliki pangsa pasar konsumen di Indonesia, kualitas produk smartphone yang dibuat Cina ini menawarkan kualitas produk telepon gengam canggih dengan fitur yang lengkap, menarik, serta memiliki tampilan yang sangat elegan serta mewah, tetapi ditawarkan dengan harga yang relatif terjangkau. Kehadiran OPPO smartphone menambah persaingan pemasaran kualitas produk smartphone berbasis android menjadi lebih ketat, dengan demikian sejumlah merek smartphone yang berbasis android dengan berbagai kelebihan dan keistimewaan dari kualitas produk masing-masing, merek-merek smartphone yang lebih dahulu masuk dan dipasarkan di Indonesia seperti Samsung, Xiaomi, Apple dan merek lainnya menjadi pesaing berat bagi OPPO smartphone dalam memasarkan kualitas produknya kepada masyarakat. Persepsi harga merupakan keinginan pelanggan untuk menggunakan harga dalam memberikan penilaian 
Pengaruh Marketing Mix.................................................Ratih Witayana, Kasidin mengenai kualitas produk (Burton et al. 1998, Sinha and Batra 1999-2000, Garretson et al. 2002 dalam Weenas, 2020).

Menurut Kotler \& Keller (2009), persepsi yaitu proses yang digunakan pada individu untuk memilih, mengorganisasi, serta menginterpretasi masukan informasi untuk menciptakan gambaran dunia yang memiliki makna. Satu hal yaitu sektor-sektor yang berpengaruh terhadap persepsi pelanggan adalah harga. Perusahaan dapat menentukan harga tinggi guna membentuk persepsi bahwa produk yang ditawarkan berkualitas. Selain itu, harga rendah dapat menjadikan persepsi pembeli untuk tidak percaya terhadap penjual sebab meragukan kualitas produk maupun pelayanannya. Seperti yang disampaikan oleh Stanton (2004) yaitu banyaknya uang (kemungkinan ditambah barang) yang ditetapkan untuk mendapatkan beberapa gabungan sebuah produk dan pelanggan yang mengikutinya. Harga berpengaruh pada tingkat penjualan, tingkat keuntungan market share yang dapat dicapai perusahaan.

Fenomena harga pada Matahari Singosaren Surakarta yaitu, perbandingan harga antara Smartphone OPPO dan VIVO yang masing-masing memiliki perbedaan harga yang cukup signifikan namun memiliki spesifikasi yang relatif sama akan sangat mempengaruhi terhadap keputusan pembelian konsumen, maka perusahaan di tuntut untuk menetapkan harga sesuai dengan kualitas kualitas produk tersebut. Promosi adalah salah satu elemen pemasaran yang berupa kegiatan yang dilaksanakan perusahaan guna mengkomunikasikan manfaat, keunggulan kualitas dan sebagainya dari kualitas produk atau jasa yang dikeluarkan oleh perusahaan tersebut sebagai konsumen. Ada beberapa pengertian promosi menurut para ahli, yaitu; Buchari Alma (2013:79) dalam Ipnu Mustofa (2020). Promosi yaitu sebuah bentuk komunikasi pemasaran dengan melakukan aktifitas pemasaran yang berusaha menyebarkan informasi, mempengaruhi dan mengingatkan pasar sasaran bahwa perusahaan dan kualitas produknya agar bersedia menerima, pembelian dan loyal pada kualitas produk yang ditawarkan perusahaan yang bersangkutan. OPPO melakukan aktivitas promosi guna menarik minat beli konsumen iklan didasari pada informasi keunggulan dan suatu kualitas produk, yang kemudian disusun sedemikian rupa sehingga mengakibatkan ketertarikan pada yang melihat atau mendengarkannya, maka promosi akan 
Pengaruh Marketing Mix..................................................Ratih Witayana, Kasidin mempengaruhi perilaku pembelian konsumen terhadap suatu kualitas produk. Kualitas pelayanan (customer service) secara umum merupakan aktivitas yang digunakan atau ditunjukkan guna memberikan kepuasan kepada setiap pelanggan, melalui kualitas pelayanan ini keinginan serta kebutuhan pelanggan dapat terpenuhi.

Menurut R.A Supriyanto kualitas pelayanan adalah suatu aktivitas yang diadakan organisasi menyangkut kebutuhan pihak konsumen serta dapat mengakibatkan kesan tersendiri, melalui kualitas pelayanan yang baik maka pelanggan akan merasa puas. Fenomena kualitas pelayanan yang terjadi pada Matahari Singosaren Surakarta adalah terciptanya kualitas pelayanan yang kurang memuaskan di hati konsumen. Konsumen smartphone OPPO yang akan diteliti pada penelitian ini yaitu pengguna dan pelanggan smartphone OPPO Matahari Singosaren di Surakarta. Pemilihan pengguna dan pelanggan di matauhari Singosaren Surakarta karena Matahari Singosaren tempat pusat nya jual beli handphone di surakarta sehingga pelanggan lebih tertarik untuk pembelian dan mengetahui berbagai informasi tidak terkecuali kualitas produk smartphone OPPO.

\section{METODOLOGI PENELITIAN}

Desain penelitian yaitu suatu kerangka kerja yang berguna untuk melaksanakan Riset pemasaran (Malholtra, 2007). Desain penelitian ini yaitu menyampaikan tata cara guna memperoleh informasi yang dibutuhkan dalam menyusun maupun menyelesaikan masalah pada penelitian. Desain penelitian yaitu dasar dalam melakukan penelitian. Oleh karena itu, desain penelitian yang baik dapat menghasilkan penelitian efektif dan efisien. Pengelompokan desain penelitian dibagi menjadi dua yaitu, eksploratif dan konklusif. Desain penelitian konklusif memiliki dua tipe yaitu deskriptif dan kausal. Pada penelitian ini menggunakan penelitian eksploratif dan deskriptif. Menurut Malhotra (2007), Penelitian eksploratif berguna untuk menyelidiki suatu permasalahan atau situasi guna mendapatkan pengetahuan serta pemahaman yang baik. Sementara itu, penelitian deskriptif bertujuan untuk menggambarkan sesuatu. 
Lokasi penelitian ini adalah konter Matahari Singosaren Surakarta di

Jl.Gatot Subroto, Kemlayan, Serengan Surakarta jawa tenggah. Obyjek yang akan diteliti pada penelitian ini yaitu pelanggan atau Smartphone OPPO yang diperoleh menggunakan kuesioner. Populasi yang menjadi objek pada penelitian ini yaitu Konsumen pada Matahari Singosaren yang menggunakan Smartphone OPPO, dengan jumlah yang tidak diketahui. Sampel adalah bagian atau wakil populasi yang diteliti. Sampel merupakan sebagian dari populasi yang memiliki karakteristik yang relatif sama dan dianggap dapat menjadi wakil dari populasi. Menurut Sugiyono (2011), teknik pengambilan sampel yang dipakai pada penelitian ini adalah metode kebetulan (accidental sampling). Sampel yang digunakan adalah sebanyak 100 orang pelangan Smartphone OPPO pada Matahari Singosaren Surakarta. Jenis data yang diperlukan dalam penelitian ini yaitu data Primer. Data primer merupakan data yang didapatkan dari sumber data secara langsung oleh peneliti yaitu berupa kuesioner yang disebarkan kepada responden. Metode pengumpulan data pada penelitian ini menggunakan metode langsung dengan cara menyebar kuesioner. Pengujian instrumen penelitian dilakukan menggunakan validitas dan reliabilitas. Uji validitas dilakukan dengan melakukan uji korelasi bivariate setiap skor indikator dengan total konstruk. Kuesioner dikatakan valid jika nilai $r$ hitung > $r$ tabel. Untuk menguji reliabilitas digunakan teknik cronbach alpha >0,60. Pengujian asumsi klasik pada penelitian ini yaitu guna memperoleh model regresi yang baik serta benar-benar dapat memberikan estimasi yang handal dan tidak bisa sesuai dengan Best Linier Unbiased Estimator (BLUE). Terdapat empat uji asumsi klasik yang mendasari regresi yaitu Uji Multikolinearitas, Uji Autokorelasi, Uji Heteroskedastisitas dan Uji Normalitas. Model Regresi adalah model yang digunakan untuk menganalisis pengaruh dari berbagai variabel independen terhadap satu variabel dependen.

Uji t digunakan untuk mengetahui signifiikasi secara parsial pengaruh variable indepeden yaitu Kualitas Produk, Presepsi harga produk, Promosi dan Kualitas Pelayanan, terhadap variable dependen yaitu keputusan pembelian konsumen Smartphone OPPO pada Matahari Singosaren Surakarta. Dikatakan apabila nilai $<0,05$. Uji F digunakan untuk mengetahui signifikasi secara simultan atau bersama-sama pengaruh variabel indepeden yaitu Kualitas Produk, Presepsi 
Pengaruh Marketing Mix..................................................Ratih Witayana, Kasidin harga produk, Promosi dan Kualitas Pelayanan, terhadap variable dependen yaitu keputusan pembelian konsumen Smartphone OPPO pada Matahari Singosaren Surakarta. Dikatakan berpengaruh apabila nilai $<0,05$. Uji koefisien determinasi adalah uji yang dilakukan guna mengetahui seberapa besar pengaruh variable alitas Produk, Presepsi harga produk, Promosi dan Kualitas Pelayanan, Dan keputusan pembelian konsumen Smartphone OPPO pada Matahari Singosaren Surakarta. Koefisien determinasi dilambangkan R2 merupakan proporsi hubungan antara variabel Y dan X.

\section{Uji Instrumen}

\section{HASIL DAN PEMBAHASAN}

a. Uji Validitas

1. Validitas item pertanyaan Variabel Kualitas Kualitas produk $\left(\mathrm{X}_{1}\right)$

Tabel 1

Hasil Uji Validitas Variabel Kualitas Produk

\begin{tabular}{|c|c|c|c|}
\hline $\begin{array}{c}\text { Item } \\
\text { Pertanyaan }\end{array}$ & $\mathrm{r}_{\text {item }}$ & $\mathrm{r}_{\text {tabel }}$ & Keterangan \\
\hline $\mathrm{X} 1.1$ & 0,491 & 0,196 & Valid \\
\hline $\mathrm{X} 1.2$ & 0,666 & 0,196 & Valid \\
\hline $\mathrm{X} 1.3$ & 0,647 & 0,196 & Valid \\
\hline $\mathrm{X} 1.4$ & 0,627 & 0,196 & Valid \\
\hline $\mathrm{X} 1.5$ & 0,438 & 0,196 & Valid \\
\hline
\end{tabular}

Sumber : Data yang diolah, 2020

Berdasarkan tabel diatas menunjukkan bahwa ke 5 item pertanyaan semua valid.

2. Validitas item pertanyaan untuk variabel presepsi harga produk $\left(\mathrm{X}_{2}\right)$ Variabel Presepsi harga produk terdiri dari 4 item pertanyaan.

Apabila $r_{\text {item }}>r_{\text {tabel, }}$ maka pertanyaan dinyatakan valid.

Tabel 2

Hasil Uji Validitas Variabel Presepsi Harga Produk

\begin{tabular}{|c|c|c|c|}
\hline $\begin{array}{c}\text { Item } \\
\text { Pertanyaan }\end{array}$ & $r_{\text {item }}$ & $R_{\text {tabel }}$ & Keterangan \\
\hline X2.1 & 0,435 & 0,196 & Valid \\
\hline X2.2 & 0,587 & 0,196 & Valid \\
\hline X2.3 & 0,604 & 0,196 & Valid \\
\hline X2.4 & 0,728 & 0,196 & Valid \\
\hline
\end{tabular}

Sumber : Data yang diolah, 2020

Berdasarkan tabel diatas menunjukkan bahwa ke 4 item pertanyaan semua valid. 
3. Validitas item pertanyaan untuk Variabel Promosi $\left(\mathrm{X}_{3}\right)$

Tabel 3

Hasil Uji Validitas Variabel Promosi

\begin{tabular}{|c|c|c|c|}
\hline Item Pertanyaan & $\mathrm{r}_{\text {item }}$ & $\mathrm{r}_{\text {tabel }}$ & Keterangan \\
\hline X3.1 & 0,637 & 0,196 & Valid \\
\hline X3.2 & 0,578 & 0,196 & Valid \\
\hline X3.3 & 0,596 & 0,196 & Valid \\
\hline X3.4 & 0,507 & 0,196 & Valid \\
\hline X3.5 & 0,251 & 0,196 & Valid \\
\hline
\end{tabular}

Sumber : Data yang diolah, 2020

Berdasarkan tabel diatas menunjukkan bahwa ke 5 item pertanyaan semua valid.

4. Validitas item pertanyaan untuk Variabel Kualitas Pelayanan $\left(\mathrm{X}_{4}\right)$

Tabel 4

Hasil Uji Validitas Variabel Kualitas Pelayanan

\begin{tabular}{|c|c|c|c|}
\hline Item pertanyaan & $\mathrm{r}_{\text {item }}$ & $\mathrm{r}_{\text {tabel }}$ & Keterangan \\
\hline X4.1 & 0,329 & 0,196 & Valid \\
\hline X4.2 & 0,674 & 0,196 & Valid \\
\hline X4.3 & 0,511 & 0,196 & Valid \\
\hline X4.4 & 0,617 & 0,196 & Valid \\
\hline X4.5 & 0,615 & 0,196 & Valid \\
\hline
\end{tabular}

Sumber : Data Primer yang diolah 2020

Berdasarkan tabel diatas menunjukkan bahwa ke 5 item pertanyaan semua valid.

5. Validitas item pertanyaan untuk Keputusan Pembelian

Keputusan Pembelian terdiri dari 4 item pertanyaan. apabila nilai $r_{i t e m}>$ $r_{\text {tabel, }}$ maka pertanyaan dinyatakan valid.

Tabel 5

Hasil Uji Validitas Variabel Keputusan Pembelian

\begin{tabular}{|c|c|c|c|}
\hline Item Pertanyaan & $\mathrm{R}_{\text {item }}$ & $\mathrm{r}_{\text {tabel }}$ & Keterangan \\
\hline Y_1 & 0,664 & 0,196 & Valid \\
\hline Y_2 & 0,681 & 0,196 & Valid \\
\hline Y_3 & 0,603 & 0,196 & Valid \\
\hline Y_4 & 0,623 & 0,196 & Valid \\
\hline
\end{tabular}

Sumber : Data Primer yang diolah

Berdasarkan tabel diatas menunjukkan bahwa ke 4 item pertanyaan semua valid.

6. Uji Reliabilitas

Tabel 6

Hasil Uji Reliabilitas

\begin{tabular}{|c|c|c|}
\hline Variabel & Alpha Cronbach & Keterangan \\
\hline Kualitas produk (X1) & 0,778 & Reliabel \\
\hline Presepsi harga produk (X2) & 0,780 & Reliabel \\
\hline Promosi (X3) & 0,729 & Reliabel \\
\hline Kualitas Pelayanan (X4) & 0,772 & Reliabel \\
\hline Keputusan Pembelian (Y) & 0,819 & Reliabel \\
\hline
\end{tabular}

Sumber : Data Primer yang diolah 2020 
Pengaruh Marketing Mix..................................................Ratih Witayana, Kasidin Berdasarkan uji reliabilitas instrumen kelima variabel yaitu Kualitas produk, Presepsi harga produk, Promosi, Kualitas Pelayanan dan Keputusan Pembelian adalah reliabel.

2. Uji Asumsi Klasik

a. Normalitas

Tabel 7

Hasil Uji Normalitas

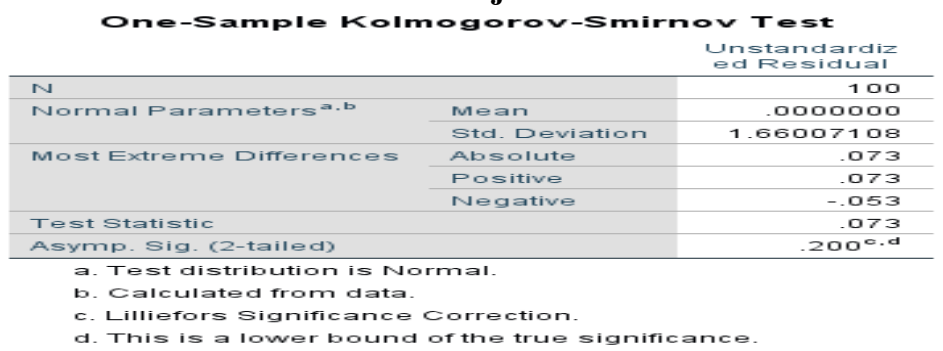

Berdasarkan hasil uji Normalitas diketahui nilai signifikansi $0.200>0.05$ maka dapat di simpulkan bahwa nilai nilai residual berdistribusi normal.

b. Uji Multikolinearitas

Tabel 8

Hasil Uji Multikolinearitas

\begin{tabular}{|c|c|c|}
\hline Variabel & Tolerance & VIF \\
\hline Kualitas produk (X1) & 0,909 & 1,100 \\
\hline Presepsi harga produk (X2) & 0,887 & 1,127 \\
\hline Promosi (X3) & 0,914 & 1,094 \\
\hline Kualitas Pelayanan (X4) & 0,957 & 1,044 \\
\hline
\end{tabular}

Sumber : Data diolah, 2020

Dari tabel coefficients diatas hasil uji multikolinearitas diketahui bahwa nilai tolerance value lebih besar dari 0,10 dan VIF lebih kecil dari 10, maka tidak terjadi multikolinearitas.

c. Uji Autokorelasi

Tabel 9

Hasil Uji Autokorelasi

Model Summary ${ }^{b}$

\begin{tabular}{|c|c|c|c|c|}
\hline$R$ & $\begin{array}{c}R \\
\text { Square }\end{array}$ & $\begin{array}{c}\text { Adjusted R } \\
\text { Square }\end{array}$ & $\begin{array}{c}\text { Std. Error of } \\
\text { the Estimate }\end{array}$ & $\begin{array}{c}\text { Durbin- } \\
\text { Watson }\end{array}$ \\
\hline 0,701 & 0,491 & 0,470 & 1,695 & 2,000 \\
\hline
\end{tabular}

Sumber: Data Primer diolah 2020

Berdasarkan hasil uji autokorelasi diatas dapat dilihat bahwa Durbin-Watson (DW) sebesar 2,000. Dari hasil tersebut dapat disimpulkan bahwa model regresi yang dihasilkan tidak terjadi masalah autokorelasi, jadi asumsi autokorelasi terpenuhi. 
Tabel 10

\begin{tabular}{|c|c|c|c|c|c|c|}
\hline \multicolumn{7}{|c|}{$\begin{array}{l}\text { Uji Hetoroskedastisitas } \\
\text { Coefficients }^{a}\end{array}$} \\
\hline \multirow[b]{2}{*}{ Model } & & \multicolumn{2}{|c|}{ Unstandardized Coefficients } & \multirow{2}{*}{$\begin{array}{l}\text { Standardized } \\
\text { Coefficients } \\
\text { Beta }\end{array}$} & \multirow[b]{2}{*}{ t } & \multirow[b]{2}{*}{ Sig. } \\
\hline & & B & Std. Error & & & \\
\hline 1 & (Constant) & 1.819 & 1.684 & & 1.080 & .283 \\
\hline & Kualitas Produk & .028 & .043 & .067 & 639 & .524 \\
\hline & Harga & -.022 & .052 & -.045 & -.422 & 674 \\
\hline & Promosi & -.097 & .053 & -.193 & -1.855 & .067 \\
\hline & Kualitas Pelayanan & .055 & .042 & .135 & 1.324 & 189 \\
\hline
\end{tabular}

Hasil uji heteroskedastisitas menunjukan semua data tersebut nilainya lebih besar dari 0.05. Hal ini berarti model regresi yang digunakan tidak terjadi heteroskedastisitas antar residual.

3. Analisis Regresi Linier Berganda

Tabel 11

Analisis Regresi Linier Berganda

\begin{tabular}{|l|r|r|r|r|r|}
\hline \multirow{2}{*}{ Model } & \multicolumn{2}{|c|}{$\begin{array}{c}\text { Unstandardized } \\
\text { Coefficients }\end{array}$} & $\begin{array}{l}\text { Standardized } \\
\text { Coefficients }\end{array}$ & \multirow{2}{*}{ t } & \multirow{2}{*}{ Sig. } \\
\cline { 2 - 5 } & \multicolumn{1}{|c|}{ B } & \multicolumn{1}{c|}{$\begin{array}{c}\text { Std. } \\
\text { Error }\end{array}$} & \multicolumn{1}{c|}{ Beta } & & \\
\hline 1. (Constant) & $-4,721$ & 2,658 & & $-1,776$ & 0,079 \\
Kulitas Produk & 0,114 & 0,068 & 0,162 & 2,109 & 0,038 \\
Harga & 0,670 & 0,082 & 0,638 & 8,211 & 0,000 \\
Promosi & 0,270 & 0,083 & 0,249 & 3,253 & 0,002 \\
Kualitas Pelayanan & 0,074 & 0,066 & 0,084 & 1,128 & 0,262 \\
\hline
\end{tabular}

a. Dependent Variabel : Keputusan Pembelian

Dari hasil diatas dapat dirumuskan model regresi sebagai berikut :

$\mathrm{Y}=0,162 \mathrm{X}_{1}+0,638 \mathrm{X}_{2}+0,249 \mathrm{X}_{3}+0,084 \mathrm{X}_{4}$

Sig $(0,038)^{* *}(0,000)^{* *}(0,002)^{* *}(0,262) *$

Persamaan regresi tersebut dapat dijabarkan sebagai berikut :

a. $\mathrm{b}_{1}=0,162$ artinya bahwa Kualitas produk berpengaruh positif terhadap Keputusan Pembelian, hal ini berarti apabila Kualitas produk ditingkatkan maka Keputusan Pembelian akan meningkat dengan asumsi Presepsi harga produk, promosi dan Kualitas Pelayanan konstan.

b. $\mathrm{b}_{2}=0,638$ artinya bahwa Presepsi harga produk berpengaruh positif terhadap keputusan pembelian, hal ini berarti apabila kualitas Presepsi harga produk ditingkatkan maka Keputusan Pembelian akan meningkat dengan asumsi Kualitas produk, promosi dan Kualitas Pelayanan konstan.

c. $b_{3}=0,249$ artinya bahwa promosi berpengaruh positif terhadap keputusan pembelian, hal ini berarti apabila promosi ditingkatkan maka Keputusan Pembelian akan meningkat dengan asumsi Kualitas produk, Presepsi harga produk dan Kualitas Pelayanan konstan.

d. $b_{4}=0,084$ artinya bahwa Kualitas Pelayanan berpengaruh positif terhadap keputusan pembelian, hal ini berarti apabila Kualitas Pelayanan ditingkatkan 
Pengaruh Marketing Mix..................................................Ratih Witayana, Kasidin maka Keputusan Pembelian akan meningkat dengan asumsi Kualitas produk, Presepsi harga produk dan promosi konstan.

4. Uji t

Tabel 12

\begin{tabular}{|c|c|c|c|c|c|}
\hline \multicolumn{6}{|c|}{ Uji t } \\
\hline $\begin{array}{c}\text { Variabel } \\
\text { Independen }\end{array}$ & $\begin{array}{c}\text { Variabel } \\
\text { Dependen }\end{array}$ & Beta & t & Sig & Keterangan \\
\hline Kualitas produk & \multirow{4}{*}{$\begin{array}{l}\text { Keputusan } \\
\text { Pembelian }\end{array}$} & 0,162 & 2,109 & 0,038 & Signifikan \\
\hline $\begin{array}{c}\text { Presepsi harga } \\
\text { produk }\end{array}$ & & 0,638 & 8,211 & 0,000 & Signifikan \\
\hline Promosi & & 0,249 & 3,253 & 0,002 & Signifikan \\
\hline $\begin{array}{l}\text { Kualitas } \\
\text { Pelayanan }\end{array}$ & & 0,084 & 1,128 & 0,262 & Tidak Signifikan \\
\hline
\end{tabular}

Berdasarkan hasil uji t diatas dapat disimpulkan sebagai berikut :

a. Kualitas produk memiliki nilai thitung sebesar 0,162 dengan nilai signifikansi $0,038<0,05$ hal ini menunjukkan bahwa Kualitas produk berpengaruh $\mathrm{t}$ signifikan terhadap Keputusan Pembelian. Hipotesis yang menyatakan bahwa Kualitas produk berpengaruh signifikan terhadap Keputusan Pembelian terbukti kebenarannya.

b. Persepsi harga produk memiliki nilai thitung sebesar 0,638 dengan nilai signifikansi $0,00<0,05$ hal ini menunjukkan bahwa Presepsi harga produk berpengaruh signifikan terhadap Keputusan Pembelian. Hipotesis yang menyatakan bahwa Presepsi harga produk berpengaruh signifikan terhadap Keputusan Pembelian terbukti kebenarannya.

c. Promosi memiliki nilai thitung sebesar 0,249 dengan nilai signifikansi $0,002<$ 0,05 hal ini menunjukkan bahwa promosi berpengaruh signifikan terhadap Keputusan Pembelian. Hipotesis yang menyatakan bahwa promosi berpengaruh signifikan terhadap Keputusan Pembelian terbukti kebenarannya.

d. Kualitas Pelayanan memiliki nilai thitung sebesar 0,084 dengan nilai signifikansi 0,262>0,05 hal ini menunjukkan bahwa Kualitas Pelayanan berpengaruh tidak signifikan terhadap Keputusan Pembelian. Hipotesis yang menyatakan bahwa Kualitas Pelayanan berpengaruh signifikan terhadap Keputusan Pembelian tidak terbukti kebenarannya. 
ANOVA ${ }^{b}$

\begin{tabular}{|c|c|c|c|c|c|}
\hline Model & $\begin{array}{c}\text { Sum of } \\
\text { Squares }\end{array}$ & df & $\begin{array}{l}\text { Mean } \\
\text { Square }\end{array}$ & $\mathrm{F}$ & Sig. \\
\hline Regression & 263,132 & 4 & 65,783 & 22,906 & 0,000 \\
\hline Residual & 272,828 & 95 & 2,872 & & \\
\hline Total & 535,960 & 99 & & & \\
\hline
\end{tabular}

a. Predictors: (Constant), Kualitas Produk, Presepsi harga produk, Promosi, dan Kualitas Pelayanan

b. Dependent Variabel: Keputusan Pembelian

Hasil Uji $F$ diketahui besarnya nilai $F=22,906$ signifikansi $0,000<0,05$ sehingga dapat disimpulkan secara simultan atau bersama-sama variabel Kualitas produk, Presepsi harga produk, Promosi dan Kualitas Pelayanan berpengaruh signifikan terhadap Keputusan Pembelian Smartphone OPPO di Matahari Singosaren Surakarta.

6. Uji Koefisien Determinasi $\left(\mathrm{R}^{2}\right)$

Tabel 14

Uji Koefisien Determinasi $\left(\mathbf{R}^{2}\right)$ Model Summaryb

\begin{tabular}{|l|l|l|l|l|}
\hline Model & $R$ & R Square & $\begin{array}{l}\text { Adjusted R } \\
\text { Square }\end{array}$ & $\begin{array}{l}\text { St d. Error of } \\
\text { the Estimate }\end{array}$ \\
\hline 1 & 0,701 & 0,491 & 0,470 & 1,695 \\
\hline
\end{tabular}

a. Predictors: (Const ant), Kualitas Produk, Presepsi harga produk, Promosi, dan Kualitas Pelayanan

b. Dependent Variabel: Keputusan Pembelian

Berdasarkan Uji koefisien determinasi ( $\mathrm{R}$ square) sebesar 0,491 yang artinya bahwa Kualitas produk, Presepsi harga produk, promosi dan Kualitas Pelayanan mampu mempengaruhi Keputusan Pembelian sebesar 49,1\%, sisanya $50,9 \%$ dipengaruhi oleh variabel lain diluar penelitian ini misalnya: lokasi, brand image, Gaya hidup, Fitur, Motivasi Konsumen dll.

\section{PEMBAHASAN}

\section{Pengaruh Kualitas produk terhadap Keputusan Pembelian.}

Nilai t hitung sebesar 2,109 dengan nilai signifikansi sebesar $0,038<0,05$ maka Kualitas produk memiliki pengaruh positif dan signifikan terhadap Keputusan Pembelian smartphone OPPO pada Matahari Singosaren Surakarta. 
Pengaruh Marketing Mix...................................................Ratih Witayana, Kasidin Apabila kualitas Kualitas produk di tingkatkan maka Keputusan Pembelian akan meningkat. Atribut Kualitas produk adalah unsur-unsur Kualitas produk yang dipandang penting oleh konsumen dan dijadikan dasar pengambilan Keputusan Pembelian. Kualitas produk smartphone OPPO sudah bagus dan memuaskan di hati konsumen, Kualitas produk smartphone sudah memiliki fitur, pilihan warna dan desain yang menarik perhatian konsumen, smartphone OPPO sudah menjadi merek terpercaya dihati konsumen sehingga apabila dilanjutkan tidak signifikan pengaruhnya terhadap Keputusan Pembelian. Hasil penelitian ini mendukung hasil penelitian relevan yang dilkakukan oleh Melati (2020) dengan judul “ Pengaruh Kualitas produk, Presepsi harga produk dan Promosi terhadap Keputusan Pembelian smartphone samsung”.Yang menjelaskan bahwa Kualitas produk berpengaruh positif dan signifikan, Akbar (2019) dengan judul "Pengaruh Kualitas produk, citra dan Kualitas Pelayanan terhadap Keputusan Pembelian Smartphone Samsung Jenis Android Kabupaten Blora”. Yang menjelaskan bahwa Kualitas produk berpengaruh positif dan signifikan.

\section{Pengaruh Presepsi harga produk terhadap Keputusan Pembelian}

Nilai t hitung sebesar 8,211 dengan nilai signifikansi sebesar $0,000<0,05$ maka Presepsi harga produk memiliki pengaruh positif dan signifikan terhadap Keputusan Pembelian smartphone OPPO pada Matahari Singosaren Surakarta. Presepsi harga produk merupakan variabel yang dapat dikendalikan dan menentukan diterima atau tidaknya suatu Kualitas produk oleh konsumen. Murah atau mahalnya Presepsi harga produk suatu Kualitas produk yang relatif sifatnya, untuk mengatakannya perlu terlebih dahulu dibandingkannya dengan Presepsi harga produk, Kualitas produk yang di Kualitas produksi perusahaan lain. Perusahaan perlu memonitor Presepsi harga produk yang diterapkan oleh para pesaing sehingga persepsi yang ditawarkan dapat menyebabkan keinginan konsumen untuk membeli. Presepsi harga produk merupakan sejumlah uang yang dibebankan atas suatu Kualitas produk atau jasa, atau jumlah dari nilai yang ditukar konsumen atas manfaat-manfaat karena memiliki atau menggunakan Kualitas produk atau jasa tersebut. Hasil penelitian ini mendukung hasil penelitian relevan yang dilkakukan oleh Kurniawan (2019) dengan judul "Pengaruh kualitas 
Pengaruh Marketing Mix...................................................Ratih Witayana, Kasidin kualitas produk, Presepsi harga produk dan iklan terhadap keputusan pembelian handpone blackberry (Studi kasus blackberry center veteran padang)" yang menyatakan bahwa Presepsi harga produk memiliki pengaruh positif dan signifikan, Akbar (2019) dengan judul "Pengaruh Kualitas produk, citra dan Kualitas Pelayanan terhadap Keputusan Pembelian Smartphone Samsung Jenis Android Kabupaten Blora". Yang menyatakan bahwa Presepsi harga produk berpengaruh signifikan, Weenas(2020) dengan judul "Kualitas Kualitas produk, Presepsi harga produk, Promosi dan Kualitas Kualitas Pelayanan berpengaruh terhadap keputusan Pembelian handphone Samsung di Samsung Mobile IT di Kota Denpasar" yang menyatakan bahwa Presepsi harga produk memiliki pengaruh positif dan signifikan.

\section{Pengaruh promosi terhadap Keputusan Pembelian}

Nilai t hitung sebesar 3,253 dengan nilai signifikansi sebesar 0,002<0,05 maka promosi memiliki pengaruh positif dan signifikan terhadap Keputusan Pembelian smartphone OPPO pada Matahari Singosaren Surakarta. Apabila promosi naik maka Keputusan Pembelian akan meningkat tetapi tidak berarti. Promosi merupakan suatu bentuk komunikasi pemasaran yaitu aktivitas pemasaran yang berusaha memaparkan informasi, mempengaruhi dan mengingatkan pasar sasaran atas perusahaan serta Kualitas produknya agar bersedia menerima, membeli dan loyal terhadap Kualitas produk yang ditawarkan perusahaan bersangkutan. Promosi yang dilakukan smartphone OPPO sudah menarik perhatian konsumen, media promosi yang diberikan smartphone OPPO sudah bagus dan menarik, pesan yang disampaikan dalam promosi smartphone OPPO sudah mencuri perhatian konsumen, jangkauan promosi yang dilakukan smartphone OPPO sangat terjangkau sehingga apabila dilanjutkan tidak signifikan pengaruhnya terhadap Keputusan Pembelian. Hasil penelitian ini mendukung hasil penelitian relevan yang dilkakukan oleh Seprianto (2018) dengan judul "Pengaruh gaya hidup, fitur dan promosi terhadap keputusan Pembelian OPPO Smartphone di kota pada padang" yang menyatakan bahwa promosi berpengaruh positif dan signifikan, Melati (2020) dengan judul “ Pengaruh Kualitas produk, Presepsi harga produk dan Promosi terhadap Keputusan Pembelian smartphone 
Pengaruh Marketing Mix..................................................Ratih Witayana, Kasidin samsung".Yang menyatakan bahwa Kualitas produk memiliki pengaruh positif dan signifikan, Weenas (2020) dengan judul "Kualitas Kualitas produk, Presepsi harga produk, Promosi dan Kualitas Kualitas Pelayanan Pengaruhnya terhadap keputusan Pembelian handphone Samsung di Samsung Mobile IT di Kota Denpasar)"yang menyatakan bahwa promosi berpengaruh positif dan signifikan.

\section{Pengaruh Kualitas Pelayanan terhadap Keputusan Pembelian}

Nilai t hitung sebesar 1,128 dengan nilai signifikansi sebesar 0,262>0,05 maka Kualitas Pelayanan memiliki pengaruh positif tetapi tidak signifikan terhadap Keputusan Pembelian smartphone OPPO pada Matahari Singosaren Surakarta. Apabila Kualitas Pelayanan di tingkatkan maka Keputusan Pembelian akan meningkat tetapi tidak berarti.Kualitas Pelayanan merupakan aktivitas yang dilakukan oleh seseorang atau kelompok orang dengan dasar faktor materi melalui sistem, prosedur dan metode tertentu dalam rangka usaha memenuhi kepentingan orang lain sesuai haknya. Kualitas Pelayanan yang dilakukan pegawai smartphone OPPO sudah bagus, menarik dan profesional, Kualitas Pelayanan yang dilakukan pegawai smartphone OPPO sudah cepat akurat dan tepat sehingga apabila dilanjutkan tidak signifikan pengaruhnya terhadap Keputusan Pembelian. Hasil penelitian ini menolak penelitian terdahulu Pratama (2018) dengan judul "Pengaruh Kualitas produk, citra dan Kualitas Pelayanan terhadap Keputusan Pembelian di Smartphone Samsung Kabupaten Blora”. Yang menjelaskan bahwa Kualitas Pelayanan memiliki pengaruh positif dan signifikan. Dan menolak penelitian terdahulu Kurniawan (2019) dengan judul "Pengaruh Presepsi harga produk, lokasi dan Kualitas Pelayanan terhadap keputusan pembelian pada Smartphone merek OPPO di Sleman DI Yogyakarta" yang menyatakan bahwa Kualitas Pelayanan memiliki pengaruh positif dan signifikan.

\section{KESIMPULAN}

1. Uji Regresi Linier Berganda : Kualitas produk, Presepsi harga produk, Promosi dan Kualitas Pelayanan memiliki pengaruh positif terhadap Keputusan Pembelian Smartphone OPPO pada Matahari Singosaren Surakarta 
Pengaruh Marketing Mix..................................................Ratih Witayana, Kasidin

2. Uji t : Variabel Kualitas produk, Presepsi harga produk, dan Promosi berpengaruh Signifikan, Kualitas Pelayanan berpengaruh tidak signifikan terhadap Keputusan Pembelian Smartphone OPPO pada Matahari Singosaren Surakarta

3. Uji F : Kualitas produk, Presepsi harga produk, Promosi dan Kualitas Pelayanan memiliki pengaruh signifikan terhadap Keputusan Pembelian secara simultan

4. Berdasarkan uji koefisien determinasi (Adjusted R Square) : Kualitas produk, Presepsi harga produk, Promosi dan Kualitas Pelayanan mampu mempengaruhi Keputusan Pembelian 49,1\% sisanya 50,9\% dipengaruhi oleh variabel lain di luar penelitian misalnya : lokasi, brand image.

\section{DAFTAR PUSTAKA}

Akbar, Kurnia. 2019. Analisis Pengaruh Harga, Brand Image, dan Atribut Produk Terhadap Keputusan Pembelian Handphone atau Smartphone Samsung Jenis Android.

Alma, Buchari. 2013. Manajemen Pemasaran dan Pemasaran jasa. Bandung : Alfabeta.

Armstrong, Gary dan Kotler, Philip. 2001. Prinsip-prinsip pemasaran, Edisi ke duabelas, Jilid 1. Jakarta Erlangga.

Ipnu Mustofa. 2020. Pengaruh Citra merek, Harga, Kualitas Produk, dan Promosi terhadap Keputusan membeli Smartphone Asus di kota Surakarta.

Kotler, Philip dan Keller, Kevin L. 2009. Manajemen Pemasaran Jilid 1. Edisi ketiga belas. Erlangga Jakarta.

Kurniawan. 2019. Pengaruh Presepsi harga produk, lokasi dan Kualitas Pelayanan terhadap keputusan pembelian pada Smartphone merek OPPO di Sleman DI Yogyakarta.

Malholtra. 2007. Marketing Research An Applied Orientation. International Edition : Pearson

Melati, Zoel. 2020. Pengaruh Kualitas produk, Presepsi harga produk dan Promosi terhadap Keputusan Pembelian smartphone Samsung.

Pratama. 2018. Pengaruh Kualitas produk, citra dan Kualitas Pelayanan terhadap Keputusan Pembelian di Smartphone Samsung Kabupaten Blora. 
Pengaruh Marketing Mix...............................................Ratih Witayana, Kasidin Seprianto 2018. Pengaruh Gaya Hidup, Fitur dan Promosi terhadap Keputusan Pembelian OPPO Smartphone di Kota Padang.

Sugiyono, Metode penelitian Kuantitatif, Kualitatif dan R \& D, Alfabeta, Bandung, 2011, 85.

Weenas, Adhimas.2020. Kualitas Kualitas produk, Presepsi harga produk, Promosi dan Kualitas Kualitas Pelayanan Pengaruhnya terhadap keputusan Pembelian Blackberry (Studi kasus blackberry Center Veteran Padang). 